\title{
Views of practice managers and general practitioners on implementing NHS Health Checks
}

\author{
Janet Krska ${ }^{1, a}$, Ruth du Plessis ${ }^{2, b}$ and Hannah Chellaswamy ${ }^{3}$ \\ ${ }^{1}$ Professor of Pharmacy Practice, School of Pharmacy and Biomolecular Sciences, Liverpool John Moores University, \\ Liverpool, UK \\ ${ }^{2}$ Public Health Development Manager, Sefton Council Public Health Department, Bootle, UK \\ ${ }^{3}$ Deputy Director of Public Health, Sefton Council Public Health Department, Bootle, UK
}

\begin{abstract}
As part of an evaluation of a contract with general practices to deliver the national NHS Health Checks programme in Sefton, North West England, we surveyed general practitioners (GPs) and practice managers (PMs) in all 55 practices.

The contract required practices to identify individuals from their practice registers with potentially high cardiovascular disease risk, and provide annual reviews. Responses were obtained from 43/178 GPs and 40/55 PMs representing 56 and 73\% of practices, respectively. There was variation in many aspects of implementation. Time and software were viewed as barriers to implementation, the increased nurse workload impacted on other services and payments were insufficient to cover costs. The main enabler for successful implementation was IT support. Fewer than half the respondents viewed the programme as beneficial to their practice.

Findings have been used to address many issues raised. Practices need more support from commissioners to help implement NHS Health Checks.
\end{abstract}

Key words: general practice; Health Checks; implementation

Received 19 May 2014; revised 25 March 2015; accepted 7 April 2015; first published online 20 May 2015

\section{Introduction}

The Department of Health in England published its strategy for improving outcomes for people with cardiovascular disease (CVD) in March 2013, which incorporates the NHS Health Check programme (Department of Health, 2013). This programme was launched in April 2009, offering an assessment of an individual's risk of developing

Correspondence to: Janet Krska, Professor of Clinical and Professional Pharmacy School of Pharmacy, Universities of Greenwich and Kent, Chatham Maritime, Kent ME4 4TB, UK. Email: j.krska@kent.ac.uk

${ }^{a}$ Current address: Professor of Clinical and Professional Pharmacy School of Pharmacy, Universities of Greenwich and Kent, Chatham Maritime, Kent ME4 4TB, UK.

${ }^{b}$ Current address: Tameside Metropolitan Borough Council, Wellington Road, Ashton-under-Lyne OL6 6DL, UK. coronary heart disease, stroke, diabetes and chronic renal disease in the population aged between 40 and 74. The NHS Health Check programme is now mandated, with responsibility for commissioning moved to local authorities, supported by Public Health England. An NHS Health Check Implementation Review and Action Plan was published in July 2013, which recognised that there had been both variation and difficulties in implementation in different areas of the country (Public Health England, 2013).

Primary Care Trusts (PCTs) in England had developed differing approaches to delivering the Health Checks programme (Graley et al., 2011). In some areas, case finding had been utilised to identify patients who are at high risk of developing CVD by using previously documented risk factors (such as age, sex, family history, blood pressure,

\footnotetext{
(C) Cambridge University Press 2015
} 
smoking status and body mass index) (Oswald et al., 2010; Cochrane et al., 2012). Such an approach has been advocated as more cost-effective than untargeted whole population approaches (Schuetz et al., 2013). Various software packages that extract relevant data from electronic medical records, imputing default values for missing data, can be used to identify high-risk individuals. Using software to create the risk register was found to save time, and enabled easier identification of those at high risk (Kilpin, 2007).

Several evaluations of the NHS Health Checks programme involving general practices have demonstrated variation in uptake rates, mode of delivery and immediate outcomes, such as rates of statin prescribing (Oswald et al., 2010; Dalton et al., 2011; Graley et al., 2011; Artac et al., 2013). Some studies have determined the views of general practice providers on various aspects of delivering NHS Health Checks, including staff training, recall procedures, risk assessment, advice provided during the Check and statin prescribing (Oswald et al., 2010; Ramsay et al., 2011; Nicholas et al., 2013). Two sought general views on the Service Level Agreements and the programme overall; however, there is little research into the experiences of implementing the Checks at GP practice level.

This paper describes a survey of both practice managers (PM) and general practitioners (GPs) on enablers and barriers to implementation of the NHS Health Check programme in the former Sefton PCT, North West England. Sefton is a diverse local authority that includes areas from both ends of the deprivation spectrum. It is served by 55 general practices with list sizes ranging from 1370 to 17100 and correspondingly varying numbers of GPs and practice nurses. The survey aimed to determine how practices were implementing Health Checks with a view to using the findings to improve the contract for the next phase and to gather views to enable both sharing of what worked and identify areas for improvement. All 55 practices in the area were providing the Check and were requested to commence with those estimated to be at high CVD risk ( $>20 \%$ over 10 years). In the first year, 2009/2010, Oberoi software (Oberoi Consulting, Derby, UK) was offered to help practices to develop a register of those individuals and all practices were provided with IT facilitator support. Annual reviews commenced during 2010/2011.

\section{Method}

\section{Instrument development}

Two questionnaires (one for GPs and one for PMs) were developed by the research team of experienced health service researchers and public health managers with advice from the Lead GP for CVD. The questionnaires were designed for postal distribution and self-completion. Both closed and open questions were used, enabling responders to provide details of implementation strategies and perceptions of the success of their strategies.

Both questionnaires sought views on the ease of establishing the high-risk register, meeting the targets set by the PCT, payment levels, perceived benefits to the practice and potential future developments of the Health Check programme. These questions used five-point semantic differential scales to enable comparisons between groups. In addition, the PM instrument sought views on all aspects of the logistics and workloads involved in developing the high-risk register and delivering Health Checks.

\section{Questionnaire distribution}

Surveys were undertaken in February and March 2011. Both questionnaires were personally addressed to PMs and GPs with a covering letter and freepost envelope for return to the PCT, and distributed to the PM in all 55 practices and all 178 GPs in these practices. Non-responding PMs were contacted by a PCT staff member by telephone and encouraged to complete the questionnaire. One reminder plus another copy of the GP questionnaire was sent by post to all GPs in each practice from which no completed questionnaire was returned, to ensure maximum practice coverage.

\section{Data analysis}

Responses were entered into SPSS version 20 for analysis. Frequency analysis was performed for closed questions, excluding missing data. Responses to free-text questions were categorised and examples selected to illustrate views.

\section{Results}

\section{Response rates}

Following the reminders, $76 \%$ of PMs (40) and $24 \%$ of GPs (43) returned a completed 
Table 1 Variation in Health Check processes between practices $(n=40)$

\begin{tabular}{|c|c|c|}
\hline Process & Method & Number (\%; 95\% Cl) \\
\hline System used & $\begin{array}{l}\text { Existing clinical system } \\
\text { Software provided } \\
\text { Both }\end{array}$ & $\begin{aligned} 26 & (65 \% ; 50.2,79.8) \\
2 & (5 \% ;-1.8,11.8) \\
12 & (30 \% ; 15.8,44.2)\end{aligned}$ \\
\hline Invitations & $\begin{array}{l}\text { Postal } \\
\text { Telephone/prescription note } \\
\text { All three }\end{array}$ & $\begin{array}{c}17(43 \% ; 27.7,58.3) \\
4(10 \% ; 0.7,19.3) \\
19(47.5 \% ; 32.0,63.0)\end{array}$ \\
\hline Appointments ${ }^{a}$ & $\begin{array}{l}\text { Left to patient } \\
\text { Pre-arranged in invitation letter } \\
\text { Both }\end{array}$ & $\begin{array}{l}26(67 \% ; 52.2,81.8) \\
8(21 \% ; 8.2,33.8) \\
5(13 \% ; 2.5,23.6)\end{array}$ \\
\hline Main Health Check provider & $\begin{array}{l}\text { Practice nurse } \\
\text { GPs } \\
\text { Health care assistant } \\
\text { Pharmacist } \\
\text { Mixture }\end{array}$ & $\begin{array}{c}25(63 \% ; 48.0,78.0) \\
7(18 \% ; 6.1,29.9) \\
5(13 \% ; 2.6,23.4) \\
1(2 \% ;-2.3,6.3) \\
2(4 \% ;-2.1,10.1)\end{array}$ \\
\hline Blood sampling ${ }^{a}$ & $\begin{array}{l}\text { All patients before Health Check } \\
\text { All patients at Health Check } \\
\text { Varied, dependent on existing data } \\
\text { Varied, dependent on existing data plus other risk factors }\end{array}$ & $\begin{aligned} 18 & (49 \% ; 32.9,65.1) \\
7 & (19 \% ; 6.4,31.6) \\
5 & (13.5 \% ; 2.5,24.5) \\
7 & (19 \% ; 6.4,31.6)\end{aligned}$ \\
\hline
\end{tabular}

${ }^{\text {a }}$ Missing data excluded.

questionnaire, the latter representing 31/55 (56\%) practices.

\section{Difficulties/limitations with establishing the high-risk register}

Over half the PMs (26/40) had used the practice's own clinical system to compile the high-risk register, with only two using the software provided (Table 1). A total of 23 of 38 responding PMs encountered no problems in developing the register, but 15 did, eight of whom cited searches or software problems, two lack of IT facilitator time and two confusion over which patients to target and risk calculation (Table 2).

\section{Health check processes and workloads involved}

A total of 18 PMs indicated their practice had used the 'Free NHS Health Check' promotional leaflets, while nine used other forms of promotion, such as posters, verbal promotion and practice newsletters. Those who used them judged their promotional strategies as either very or moderately successful. Three of nine using no promotional methods said they would use leaflets in future.

A mixture of ways of inviting patients for Health Checks were used, with approximately half the PMs reporting the use of multiple methods, with most leaving it to the patient to make the appointment, as opposed to giving pre-arranged appointments (Table 1). Three PMs reported their method of appointments was unsuccessful, including two who required patients to make appointments. Most practices $(22 ; 73 \%)$ contacted patients three times before excluding them. While most practices also saw patients opportunistically $(30 ; 77 \%)$, others had requested that patients underwent fasting blood testing before offering the Health Check. A total of 18 practices invited patients for blood tests before their Health Check appointment, with other practices adopting different strategies (Table 1), including seven which took blood samples at the Health Check appointments, meaning that a CVD risk score was not available at the review.

Only 17 PMs reported their practice had a lead GP for the project. The majority of PMs $(34 ; 85 \%)$ indicated that one person was responsible for co-ordinating the high-risk register, most frequently the IT facilitator or PM (21), while nurses were mostly responsible for conducting the Health Checks (25), assessing and communicating risk and lifestyle advice and recording data (Table 1). Both nurses and health care assistants took blood samples. Almost all respondents indicated that both creating the register $(33 ; 83 \%)$ and conducting Health Checks $(37 ; 93 \%)$ had an impact on practice workload, in particular 12 said this 
Table 2 Examples of free-text comments, illustrating various aspects of implementing NHS Health Checks

\begin{tabular}{|c|c|c|}
\hline Aspect of Health Check & Comment & Source \\
\hline \multirow[t]{3}{*}{ Practical issues } & $\begin{array}{l}\text { Initially we made appointments but encountered many DNA's so we asked } \\
\text { patients to have blood test first and then to contact us to make their } \\
\text { appointment. This worked much better }\end{array}$ & PM 9 \\
\hline & $\begin{array}{l}\text { Patients seem confused about what this check is for and look at it as just } \\
\text { another health check, therefore causes a lot of DNA's (despite leaflet info } \\
\text { sent out with invitation letter) }\end{array}$ & PM 22 \\
\hline & $\begin{array}{l}\text { It seemed on the surface (at the beginning) to be a worthwhile project. It has } \\
\text { turned out to be difficult to implement and get patients to come in. Some } \\
\text { patients are not interested in improving their health it would seem? }\end{array}$ & GP 14 \\
\hline \multirow[t]{2}{*}{ Work pressure } & $\begin{array}{l}\text { Patients called back for further appointments for nurse have meant less } \\
\text { appts for nurse for other patients }\end{array}$ & PM 26 \\
\hline & $\begin{array}{l}\text { It has added stress for small reward, but had added a 'guilt' element that we } \\
\text { have not succeeded in reaching targets }\end{array}$ & PM 10 \\
\hline \multirow[t]{3}{*}{ Payments } & Not really interested in the money & PM 4 \\
\hline & Some patients need more work/input - enhanced payments? & GP 11 \\
\hline & $\begin{array}{l}\text { The workload is enormous. I have not been able to work out how the } \\
\text { practice is going to fund this both with } 1 \text {. Extra workload (clearly the } \\
\text { money does not lend itself to an extra member of staff, nor does the } \\
\text { opportunistic screening for those hard to pick up otherwise. 2. Extra } \\
\text { prescribing costs. 3. Extra cost of lab tests. 4. Extra follow up appointments }\end{array}$ & GP 12 \\
\hline \multirow[t]{3}{*}{$\begin{array}{l}\text { Views on the Health Checks } \\
\text { programme in general }\end{array}$} & $\begin{array}{l}\text { I think the CVD [Check] is a great thing to have for patients as it gives the } \\
\text { patient } 20 \text { minutes with a HCA for any questions they have }\end{array}$ & PM 32 \\
\hline & $\begin{array}{l}\text { The entire vascular health check programme is pretty much a waste of time } \\
\text { and resources }\end{array}$ & GP 37 \\
\hline & $\begin{array}{l}\text { Lack of interest and uptake from the younger practice population? due to } \\
\text { accessibility of appointments if working etc. - Would be a more beneficial } \\
\text { health promotion strategy if lower ages targeted more. Increase chance of } \\
\text { any lifestyle changes having impact }\end{array}$ & GP 8 \\
\hline
\end{tabular}

$\mathrm{GP}=$ general practitioner $\mathrm{PM}=$ practice manager .

affected mostly nurse time, eight administrative staff time and three GP time, with follow-ups also causing increased GP (four) and nurse (three) workload, having consequences for other services (Table 1).

\section{Barriers and enablers}

A total of 23 PMs described barriers to establishing the high-risk register and using it to instigate NHS Health Checks. The most frequent barriers were time constraints/pressure of work (nine) and difficulties with the clinical system, software or errors in existing data (nine). Other issues raised included previous poor recording, patients not attending and lack of clinician input; 14 cited enabling factors including input and support of the IT facilitator (seven), software (three) and high quality pre-existing data (two).

Responses from PMs were used to identify key operational aspects of delivery and general views in practices with varying degrees of perceived success (Table 3), and an overall summary of enabling and inhibiting factors for successful implementation was developed (Table 4).

\section{Views on the NHS Health Checks programme and its implementation}

Most GPs were positive about the NHS Health Check programme in general; $22(51 \%)$ viewed the programme as important and $24(54 \%)$ beneficial to their patients, while $32(74 \%)$ agreed with the decision to target high-risk patients. Only two viewed the NHS Health Checks programme negatively, considering it to be waste of both time and resources (Table 2), but several others expressed concern about confused public perceptions potentially resulting in low uptake.

In relation to the specific service commissioned by the PCT, GPs and PMs had similar views on the ease of compiling the register of high-risk patients, 
Table 3 Experiences and views of developing a register of patients at high CVD risk and implementing Health Checks, illustrating diversity

\begin{tabular}{|c|c|c|c|c|}
\hline Example & Developing register & $\begin{array}{l}\text { Implementing } \\
\text { checks }\end{array}$ & Project management & Overall view \\
\hline A - Unsuccessful & $\begin{array}{l}\text { Used existing clinical } \\
\text { system, lacked time } \\
\text { and manpower, had } \\
\text { problems }\end{array}$ & $\begin{array}{l}\text { No strategy for } \\
\text { promotion, inviting } \\
\text { patients, for blood } \\
\text { tests or prioritising } \\
\text { patients. Had no } \\
\text { recall system and } \\
\text { did not follow-up } \\
\text { non-attenders }\end{array}$ & $\begin{array}{l}\text { Had no lead GP and } \\
\text { no-one else taking } \\
\text { responsibility for } \\
\text { any aspect of the } \\
\text { project }\end{array}$ & $\begin{array}{l}\text { Not at all beneficial: } \\
\text { time, manpower } \\
\text { constraints and } \\
\text { confusion over } \\
\text { what was required }\end{array}$ \\
\hline $\begin{array}{l}\text { B - Partially } \\
\text { successful }\end{array}$ & $\begin{array}{l}\text { Used existing clinical } \\
\text { system, but had } \\
\text { problems with this } \\
\text { and with submitting } \\
\text { data. IT facilitator } \\
\text { had responsibility } \\
\text { for these aspects }\end{array}$ & $\begin{array}{l}\text { Used prescription } \\
\text { notes, asking } \\
\text { patients to make } \\
\text { appointments: not } \\
\text { at all successful. } \\
\text { Had no promotional } \\
\text { strategy, did not } \\
\text { follow-up non- } \\
\text { attenders. Blood } \\
\text { tests depended on } \\
\text { existing data in } \\
\text { records, but not } \\
\text { successful }\end{array}$ & $\begin{array}{l}\text { Had no lead GP. The } \\
\text { practice nurse was } \\
\text { responsible for all } \\
\text { practical aspects of } \\
\text { arranging and } \\
\text { undertaking the } \\
\text { Checks }\end{array}$ & $\begin{array}{l}\text { Not beneficial: main } \\
\text { barrier time, plus } \\
\text { lack of clarity over } \\
\text { PCT requirements }\end{array}$ \\
\hline $\begin{array}{l}\text { C- Moderately } \\
\text { successful }\end{array}$ & $\begin{array}{l}\text { Used mixture of } \\
\text { software, but } \\
\text { expressed } \\
\text { confusion over } \\
\text { calculating risk } \\
\text { scores }\end{array}$ & $\begin{array}{l}\text { Did not use leaflets, } \\
\text { sent three letters } \\
\text { before excluding } \\
\text { patients, did blood } \\
\text { tests first, viewed as } \\
\text { very successful }\end{array}$ & $\begin{array}{l}\text { Had no lead GP, } \\
\text { IT facilitator } \\
\text { co-ordinated } \\
\text { register, } \\
\text { administrator } \\
\text { responsible for } \\
\text { inviting patients, } \\
\text { no-one responsible } \\
\text { for reviewing } \\
\text { patients and } \\
\text { recording data }\end{array}$ & $\begin{array}{l}\text { Not at all beneficial, } \\
\text { despite previous } \\
\text { CVD work and } \\
\text { comprehensive } \\
\text { computer records. } \\
\text { Software issues } \\
\text { seen as main } \\
\text { problem }\end{array}$ \\
\hline D - Very successful & $\begin{array}{l}\text { Used existing clinical } \\
\text { system, had no } \\
\text { problems creating } \\
\text { register or } \\
\text { submitting data }\end{array}$ & $\begin{array}{l}\text { Did not use leaflets, } \\
\text { sent three letters } \\
\text { before excluding } \\
\text { patients, did blood } \\
\text { tests first, viewed as } \\
\text { very successful }\end{array}$ & $\begin{array}{l}\text { Had a GP lead, office } \\
\text { manager } \\
\text { responsible for } \\
\text { co-ordinating } \\
\text { register, inviting } \\
\text { patients, ensuring } \\
\text { Checks completed } \\
\text { and data recorded. } \\
\text { Health care } \\
\text { assistant did most } \\
\text { Checks }\end{array}$ & $\begin{array}{l}\text { Beneficial, PCT } \\
\text { targets very easy to } \\
\text { achieve: made good } \\
\text { use of IT facilitator }\end{array}$ \\
\hline $\begin{array}{l}\text { E - Different } \\
\text { approach }\end{array}$ & $\begin{array}{l}\text { Used existing clinical } \\
\text { system, had } \\
\text { problems creating } \\
\text { the register, but not } \\
\text { in submitting data }\end{array}$ & $\begin{array}{l}\text { Used leaflets with } \\
\text { letters plus } \\
\text { opportunistic } \\
\text { promotion: } \\
\text { moderately } \\
\text { successful. Patients } \\
\text { invited for blood } \\
\text { tests before Checks: } \\
\text { moderately } \\
\text { successful }\end{array}$ & $\begin{array}{l}\text { Had no GP lead; } \\
\text { pharmacist } \\
\text { responsible for } \\
\text { co-ordinating } \\
\text { register, inviting } \\
\text { patients, } \\
\text { conducting Checks } \\
\text { and recording data. } \\
\text { HCA took bloods }\end{array}$ & $\begin{array}{l}\text { Very beneficial: } \\
\text { resulted in much } \\
\text { improved } \\
\text { recording, viewed } \\
\text { as key facilitator }\end{array}$ \\
\hline
\end{tabular}

$\mathrm{GP}=$ general practitioner CVD = cardiovascular disease; PCT = Primary Care Trusts; HCA = health care assistant. 
Table 4 Key aspects of implementing aspects of Health Checks for patients with high CVD risk

\begin{tabular}{ll}
\hline Aspects resulting in successful implementation & Aspects potentially contributing to less success \\
\hline Clear understanding of the project & Lack of awareness of project purpose/benefit \\
One person leading and co-ordinating project & No clear lead \\
Well-organised invitations and appointments & Perceived time and manpower constraints \\
Maximise involvement of information facilitator & Dependent on information facilitator \\
Pre-existing good recording systems & Searches not accurate \\
Multiple invitation methods & Single invitation method via prescription note \\
Good recall system & No recall system: patients not followed up
\end{tabular}

Common problems affecting uptake

Difficulty accessing hard-to-reach groups

Patients lack interest in their own health

Low uptake by younger population

CVD = cardiovascular disease

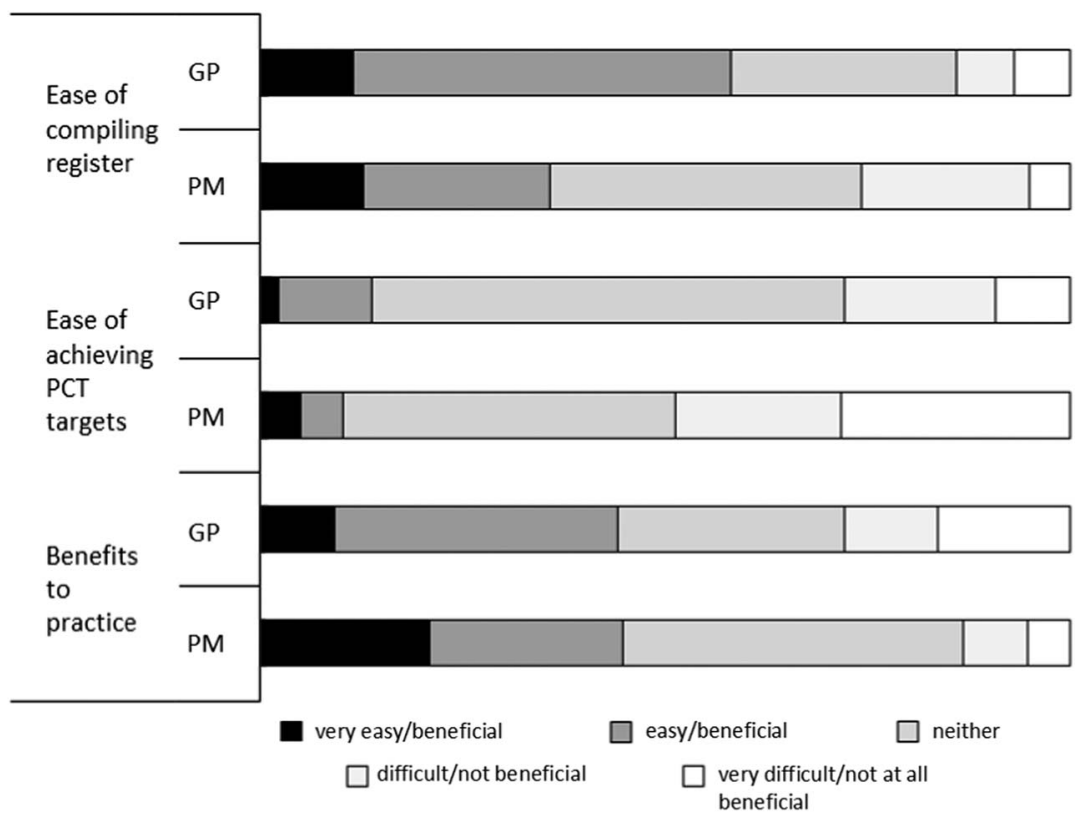

Figure 1 GP and PM views on implementing NHS Health Checks. GP = general practitioner; PM = practice manager

achieving the PCT-set targets/payment thresholds and benefits to practices. Compiling the register was viewed as easier than meeting targets. Overall, fewer than half the GP and PM responders viewed the overall project as beneficial to the practice (19/43 GPs and 17/38 PMs) (Figure 1). More PM respondents (18) than GP respondents (seven) considered that payments provided by the PCT covered practice costs. Two PMs felt money was a minor concern, while one GP proposed a differential payment depending on individual patient factors (Table 2).

A majority of respondents from both groups agreed that the service should be extended to other priority groups, but there was relatively less support for other possible developments, including near patient testing, centralised nursing team, outreach and allowing other practices to offer NHS Health Checks on their behalf (Figure 2). 


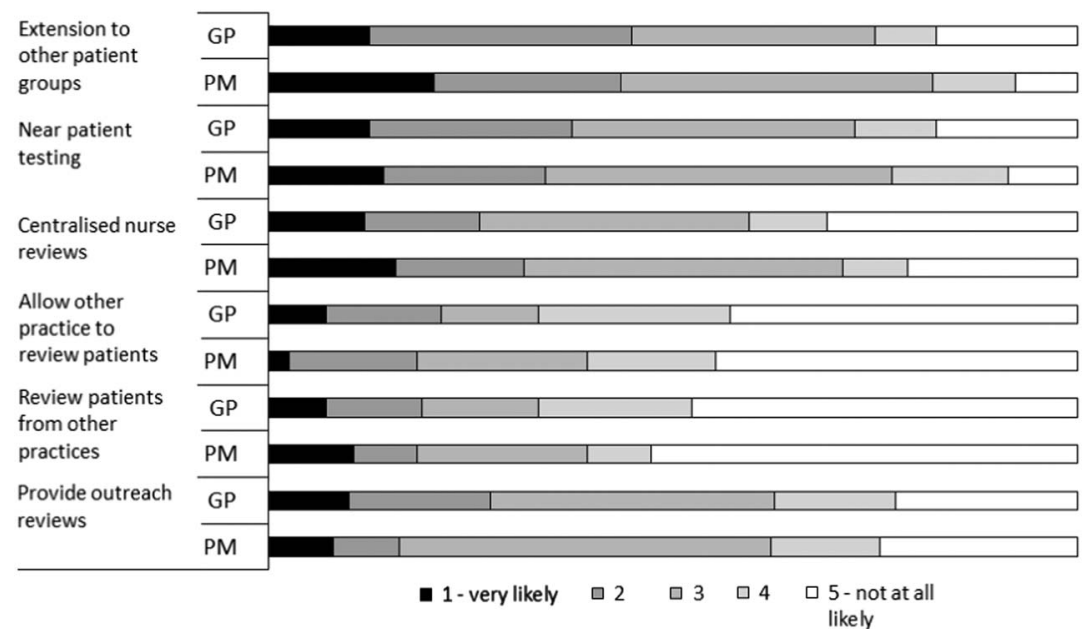

Figure 2 GP and PM views on possible future developments in the NHS Health Check programme. GP $=$ general practitioner; $\mathrm{PM}=$ practice manager

\section{Discussion}

The findings describe in detail the extent to which practices vary in their delivery of the NHS Health Checks programme, the use of promotional methods, invitation methods, appointment strategies, blood sampling and administration, as well as delivery of actual reviews. The results have implications for delivery of the programme through general practice. However, the response rate from GPs was low, therefore their views reported here must be regarded with caution. In addition, $24 \%$ of PMs did not respond, the survey was only carried out in one area of England and, because of its anonymous nature, was not linked to uptake rates. The PM survey provided details of both what worked and problems in implementation of the local approach taken to the national programme. Most GPs did have positive views concerning the potential benefits of the NHS Health Checks programme; however, fewer viewed the local implementation as beneficial to their practice. Managers generally agreed that the programme's impact on workload had knock-on effects on other services and both managers and GPs felt that payments were insufficient to cover costs. There was relatively little support for developing different delivery methods. Negative views among both GPs and PMs have been reported previously (Research Works, 2013).

Primary Health Care Research \& Development 2016; 17: 198-205
Problems with establishment of the practice registers may have contributed to negative views of the programme, possibly resulting from the approach taken to implementation where practices developed their own lists. This contrasted with other areas, where practices were provided with lists of individuals potentially at high risk (Oswald et al., 2010; Cochrane et al., 2012) or received visits from software specialists (Kilpin, 2007). The lack of GP leadership could have contributed to dissatisfaction with the contract, as could the lack of clarity of PCT requirements and concerns about capacity and time constraints, all issues previously reported elsewhere (Cochrane et al., 2012; Nicholas et al., 2013; Research Works, 2013). Our survey was carried out before publication of a Cochrane review suggesting the NHS Health Checks programme was not supported by evidence, which generated considerable subsequent debate in the professional press (Krogsbøll et al., 2012).

Importantly, our surveys were designed using many open questions which enabled respondents to provide details of what was successful and views on the programme and its implementation. These enabled a unique analysis of elements potentially contributing to successful implementation, enabling perceived successful strategies to be shared and changes made to elements of the contract. The survey findings have since been used to address many issues raised including: modification 
of data searches enabling easier management of call and recall, supply of locally developed patient information leaflets, simplifications to payment processes, changes to the requirement for fasting blood tests. In addition, training has also been provided on signposting and supporting patients with lifestyle changes. Identification of high-risk individuals proved difficult for some practices, and support with this is essential if practices are to target this population. Our study suggests that, if general practices are to continue to provide NHS Health Checks in general, local authority commissioners need to ensure effective engagement with practices through establishment of clear leadership within each practice, proactively support implementation and give greater consideration to ensuring that payment structures cover delivery costs. Gathering feedback from practice staff is an essential mechanism for enabling successful delivery and development of the programme. Such feedback should include the views and experiences of those involved directly in delivery, that is, administration staff, practice nurses health care assistants and other staff.

\section{Acknowledgement}

Julia Taylor was involved in the design and distribution of the questionnaires.

\section{Financial Support}

The study was funded by Sefton PCT.

\section{Conflicts of Interest}

None.

\section{Ethical Standards}

The authors assert that all procedures contributing to this work comply with the ethical standards of the relevant national and institutional guidelines on human experimentation and with the Helsinki Declaration of 1975, as revised in 2008. This evaluation was approved by Liverpool John Moores
University (LJMU) Research Ethics Committee and Sefton PCT.

\section{References}

Artac, M., Dalton, A., Majeed, A., Cara, J., Huckvale, K. and Millett, C. 2013: Uptake of the NHS Health Check programme in an urban setting. Family Practice 30, 426-35.

Cochrane, T., Gidlow, C.J., Kumar, J., Mawby, Y., Iqbal, Z. and Chambers, R.M. 2012: Cross-sectional review of the response and treatment uptake from the NHS Health Checks programme in Stoke on Trent. Journal of Public Health 35, 92-98.

Dalton, A.R.H., Bottle, A., Okoro, C., Majeed, A. and Millett, C. 2011: Uptake of the NHS Health Check programme in a culturally diverse setting: cross-sectional study. Journal of Public Health 33, 422-29.

Department of Health. 2013: Cardiovascular disease outcomes strategy: improving outcomes for people with or at risk of cardiovascular disease. London: Department of Health.

Graley, C.E.M., May, K.F. and McCoy, D.C. 2011: Postcode lotteries in public health - the NHS Health Checks programme in North West London. BMC Public Health 11, 738.

Kilpin, A. 2007: Oberoi clinical observations: CVD primary prevention software. Pilot evaluation. North West London Cardiac Network. Retrieved 7 March 2013 from http://www. nwlcn.co.uk/primarycaresubgroup/pilotevaluationjuly07ak.pdf

Krogsbøl, L.T., Jørgensen, K.J., Larsen, C.G. and Gøtzsche, P.C. 2012: General health checks in adults for reducing morbidity and mortality from disease: Cochrane systematic review and meta-analysis. BMJ 345, e7191.

Nicholas, J.M., Burgess, C., Dodhia, H., Miller, J., Fuller, F., Cajeat, E. and Gulliford, M.C. 2013: Variations in the organization and delivery of the 'NHS health check' programme in primary care. Journal of Public Health 35, 85-91.

Oswald, N., McNaughton, R., Watson, P. and Shucksmith, J. 2010. Evaluation of the Tees vascular assessment programme: main project report. Centre for Health and Social Evaluation, Teesside University.

Public Health England. 2013: NHS Health Check implementation review and action plan. London: Public Health England.

Ramsay, S., Davidson, J., Taylor, S. and Olughu, C. 2011: Evaluation of NHS Health Check PLUS Community Outreach Programme in Greenwich.

Research Works NHS Greenwich. 2013: Understanding the implementation of NHS Health Checks. St Albans.

Schuetz, C.A., Alperin, P., Guda, S., van Herick, A., Cariou, B., Eddy, D., Gumprecht, J., Nicolucci, A., Schwartz, P., Wareham, N.J., Witte, D.R. and Smith, U. 2013: A standardized vascular disease Health Check in Europe: a cost-effectiveness analysis. PLoS One 8, e66454. 